\title{
Организация государственной защиты персонала пенитенциарных учреждений некоторых стран Западной Европы, Северной Америки и Азии
}

\author{
о. в. КИРИловский \\ Вологодский институт права и экономики ФСИН России, г. Вологда, Россий- \\ ская Федерация
}

ORCID: https://orcid.org/0000-0001-8718-396X, e-mail: kirilovskiy77@mail.ru

\begin{abstract}
Р е ферат
Введение: статья посвящена изучению опыта некоторых стран Западной Европы (Италии, Германии, Австрии и Нидерландов), Северной Америки (Соединенных Штатов Америки и Канады) и Азии (Монголии и Японии) в сфере обеспечения государственной защиты персонала пенитенциарных учреждений. Целью данного обобщения является выявление актуальных примеров правового регулирования и организации государственной защиты государственных служащих, в том числе персонала пенитенциарных учреждений, для внедрения в отечественную практику. Методы: в работе использованы общенаучные (анализ, синтез, индукция и т. д.) и конкретно-социологические (сравнительно-правовой, социологический, статистический, компаративистский) методы познания. Результаты: по итогам компаративистских исследований установлено, что правовая основа государственной защиты персонала пенитенциарных учреждений Монголии и Японии не имеет обособленной унифицированной формы. Нормы, закрепляющие правовые и социальные гарантии сотрудников, содержатся в нескольких законах и конкретизирующих их подзаконных актах. Опыт стран Западной Европы и Америки указывает на то, что деятельность по обеспечению государственной защиты сконцентрирована и реализуется специально созданным органом, имеющим широкий круг полномочий. Особое внимание в данных государствах уделяется вопросу обособленного финансирования программ защиты государственных служащих и лиц, оказывающих содействие правосудию. Обсуждение: особое внимание обращается на то, что правовые и организационные аспекты обеспечения государственной защиты персонала пенитенциарных учреждений некоторых зарубежных стран имеют положительные черты. Отдельные примеры зарубежного опыта могут быть использованы в правотворческой и правоприменительной деятельности Российской Федерации.

Ключевые слова: персонал пенитенциарных учреждений; зарубежный опыт; государственная защита; уголовно-исполнительная система; меры безопасности; меры правовой и социальной защиты.
\end{abstract}

12.00.11 - Судебная деятельность, прокурорская деятельность, правозащитная и правоохранительная деятельность.

Для цитирования: Кириловский О. В. Организация государственной защиты персонала пенитенциарных учреждений некоторых стран Западной Европы, Северной Америки и Азии. Пенитенциарная наука, 2021, т. 15, № 2 (54), с. 291-300. DOI 10.46741/2686-9764-2021-15-2-291-300.

\section{Organizing State Protection of the Personnel of Penal Institutions in Some Countries of Western Europe, North America and Asia}

\section{OLEG V. KIRILOVSKII}

Vologda Institute of Law and Economics of FSIN Russia, Vologda, Russian Federation

ORCID: https://orcid.org/0000-0001-8718-396X, e-mail: kirilovskiy77@mail.ru 
Abstract

Introduction: the paper investigates the experience of some countries of Western Europe (Italy, Germany, Austria and The Netherlands), North America (the U.S. and Canada) and Asia (Mongolia and Japan) in the field of state protection of penitentiary personnel. The aim of summarizing the experience of these countries is to identify relevant examples of legal regulation and organization of state protection of civil servants, including prison staff, for the purpose of implementation of this experience in Russian practice. Methods: we use general scientific (analysis, synthesis, induction, etc.) and specific sociological methods of cognition (comparative-legal, sociological, statistical, comparative). Results: having conducted the comparative study, we find that Mongolia and Japan do not have a separate unified legal framework for state protection of penitentiary personnel. The norms that establish the legal and social guarantees of employees are contained in several laws and by-laws that specify them. The experience of the countries of Western Europe and America indicates that the activities aimed at ensuring state protection are concentrated and implemented by a specially created body with a wide range of powers. In these countries, special attention is paid to the issue of separate funding of programs for the protection of state servant sand persons who assist justice. Discussion: we highlight the fact that the legal and organizational aspects of ensuring state protection of the personnel of penitentiary institutions in some foreign countries have positive aspects. Some examples of foreign experience can be used in law-making and law enforcement activities in the Russian Federation.

Keywords: penitentiary personnel; foreign experience; state protection; penal system; security measures; legal and social protection measures.

12.00.11 - Judicial activities, prosecutor's activities, human rights and law enforcement activities.

F or c it ation: Kirilovskii O.V. Organizing state protection of the personnel of penal institutions in some countries of Western Europe, North America and Asia. Penitentiary Science, 2021, vol. 15, no. 2 (54), pp. 291-300. DOl 10.46741/2686-9764-2021-15-2-291-300.

\section{Введение}

Современное состояние уголовно-исполнительной системы Российской Федерации, а также ее реформирование в условиях нестабильной геополитической обстановки, оптимизации государственных расходов указывает на новые вызовы, а также подчеркивает актуальность вопросов государственной защиты интересов сотрудников УИС и их близких.

Сотрудники УИС наиболее подвержены преступному посягательству со стороны криминально настроенных граждан, поскольку находятся в непосредственном контакте с осужденными. Актуальность вопроса об обеспечении безопасности персонала учреждений и органов УИС не вызывает сомнений, что подтверждается ведомственными статистическими данными. Так, в 2019 г. в учреждениях УИС зарегистрировано 300 (в 2018 г. - 175, 2017 г. - 175, 2016 г. - 194) фактов противоправных действий (насилия, угроз, оскорблений) со стороны лиц, содержащихся в данных учреждениях, в отношении персонала. Только за первый квартал 2020 г. совершено 98 случаев посягательств (АППГ - 64).

Особую озабоченность вызывают случаи преступных посягательств, в результа- те которых сотрудникам были причинены телесные повреждения различной степени тяжести. В их числе 86 фактов, связанных с посягательством на личную неприкосновенность сотрудников УИС [13, с. 19-34] (2018 г. -55 [12, с. 38], 2017 г. - 46 [11, с. 39], 2016 г. - 41 [10, с. 33]). Только за последний год рост указанных противоправных деяний составил $36 \%$.

В социологическом исследовании данной сферы правоотношений приняли участие 1200 аттестованных сотрудников различных служб и отделов учреждений из 55 территориальных органов УИС, которые представляют все федеральные округа Российской Федерации (Центральный округ - 13 органов, Северо-Западный округ - 7 органов, Южный округ - 4 органа, Северо-Кавказский округ - 3 органа, Приволжский округ - 11 органов, Уральский округ - 4 органа, Сибирский округ - 8 органов, Дальневосточный округ - 5 органов). По его результатам выяснилось, что каждый четвертый респондент (26\%) оценивает свой уровень защищенности как высокий, остальная часть - как низкий и средний, что говорит о наличии проблем в правовом регулировании и организации деятельности по обеспечению государственной защиты сотрудников УИС. 
Под системой такого правового явления, как государственная защита сотрудников УИС и ихблизких, следует понимать внутреннее ее строение, совокупность взаимосвязанных и взаимозависимых элементов и частей: субъектов, содержания, оснований, целей и процедуры. Субъектами выступают подразделения собственной безопасности, отделы специального назначения и др. Содержание ее образует система мер безопасности, социальной и правовой защиты, предусмотренных Федеральным законом от 20.04.1995 № 45-Ф3 «О государственной защите судей, должностных лиц правоохранительных и контролирующих органов» (далее - Закон о государственной защите). Правовым основанием является подтвержденный статус защищаемого лица, а фактическим - посягательство на жизнь, здоровье и имущество сотрудников УИС и их близких в связи с исполнением ими своих служебных обязанностей. Цель защиты - это обеспечение прав и законных интересов, защита жизни, здоровья и имущества сотрудников УИС и их близких, а также возмещение причиненного вреда. Процедура - установленный Законом о государственной защите или иными нормативными правовыми актами порядок.

\section{Обсуждение}

Для более обстоятельного исследования вопроса организационного обеспечения государственной защиты сотрудников УИС необходимо обратиться к зарубежному опыту в данной сфере, используя компаративистский метод познания.

В отечественном правовом поле существует ряд нормативных правовых актов по обеспечению государственной защиты государственных служащих правоохранительных органов, однако с полной уверенностью сказать, что они эффективно реализуются на практике, нельзя. Особую роль в развитии законодательства в данной сфере должны играть нормы международного права и успешный опыт зарубежных стран, который можно использовать в России.

Исследование зарубежного опыта организации обеспечения защиты персонала пенитенциарных учреждений с учетом общности государственных правовых систем и особенностей функционирования систем управления пенитенциарными учреждениями в различных странах позволяет условно выделить три значительные группы:
1) страны Содружества Независимых Государств (далее - СНГ);

2) страны Азиатско-Тихоокеанского региона;

3) страны Европы и Северной Америки.

На постсоветском пространстве институт государственной защиты развивался параллельно с законодательством России, в силу чего отечественное законодательство в данной области выступает базовым, исходным правовым инструментом. Так, в конце 1998 г. на одном из заседаний стран участниц СНГ был принят Модельный закон о государственной защите государственных служащих в правоохранительной сфере (далее - Модельный закон). В основе указанного документа лежат общепризнанные принципы и стандарты ООН и Совета Европы в области государственной защиты государственных служащих, свидетелей, потерпевших и иных участников уголовного процесса.

Сравнительный анализ данного нормативного акта и Закона о государственной защите показал, что Модельный закон точно воспроизводит первоначальную редакцию отечественного Закона о государственной защите [8, с. 112].

Законодательство стран СНГ в сфере государственной защиты судей, должностных лиц правоохранительных и контролирующих органов основано на положениях Модельного закона. Поэтому полагаем, что дальнейшее исследование целесообразно вести в направлении изучения опыта по обеспечению государственной защиты персонала пенитенциарных учреждений на примере некоторых стран из двух оставшихся групп.

Обратимся к соответствующей практике стран Азиатско-Тихоокеанского региона.

Исполнение уголовных наказаний в Монголии осуществляет Главное управление исполнения судебных решений, которое входит в состав Министерства юстиции и внутренних дел Монголии (ГУИСР МЮ и ВД Монголии). Сотрудники пенитенциарных учреждений Монголии относятся к персоналу полиции, поэтому исследование вопросов их государственной защиты будет рассмотрено на примере сотрудников полиции Монголии.

Государственная защита сотрудников полиции Монголии основана на положениях Конституции Монголии. Она содержит нормы, обеспечивающие социальные гарантии сотрудникам полиции по старости, при 
утрате трудоспособности, в случае ухода за родившимся ребенком до трех лет и в силу других причин. Имущественный ущерб, причиненный сотруднику полиции в связи с выполнением им своих служебных обязанностей, возмещается органами полиции, а впоследствии в порядке регресса взыскивается с виновного лица.

Гарантии государственной защиты судей и государственных служащих в правоохранительной сфере Монголии можно охарактеризовать как меры опосредованной защиты. По мнению М. Батаева, они «предусматривают защиту прав и законных интересов сотрудников правоохранительных органов посредством реализации осуществления правоприменительной деятельности. Меры непосредственной защиты прав и законных интересов должностных лиц правоохранительных органов рассматриваются как предоставленное государством право в определенных случаях применять личное оружие, физическую силу, специальные средства, а также использовать иные не запрещенные законом способы защиты» [1, c. 25].

3. Цэрэнбат в своем диссертационном исследовании подчеркнул актуальность и определил значение государственной защиты сотрудников полиции Монголии, пришел к выводу о необходимости дальнейшего совершенствования ее механизмов. Автор отметил, что нормативное закрепление мер правовой и социальной защиты государственных служащих правоохранительных органов не носит консолидированного характера. Меры государственной защиты данной категории закреплены в нескольких законах Монголии: «Об органах полиции», «О государственной службе», «О службе в полиции», «О социальном страховании жизни и здоровья военнослужащих, граждан, призванных на военные сборы, служащих внутренних, пограничных войск, сотрудников полиции, государственной противопожарной службы, учреждений и органов уголовно-исполнительной системы, разведчиков», «О пенсиях, субсидиях военнослужащих» и др. [14, с. 55-56].

Закон Монголии от 01.02.2014 № 46 «О службе в полиции» дополняется подзаконными актами, ведомственными приказами, инструкциями, распоряжениями, которые конкретизируют и разъясняют его общие положения, в частности вопросы социальной и правовой защиты сотрудников полиции.
На основании данного закона в 2010 г. издан приказ Главного управления полиции (ГУП) Монголии № 3691, которым утверждено Руководство по защите интересов должностных лиц органов полиции и внутренних войск. Этот документ содержит цели, задачи, направления указанной деятельности, правовые и организационные аспекты ее реализации, а также ставит целью увеличение финансирования обозначенных категорий государственных правоохранительных служащих. Задачами в сфере государственной защиты являются:

- обеспечение трудовой безопасности, снижение производственного травматизма;

- усовершенствование менеджмента, управления и кадрового обеспечения;

- защита законных интересов сотрудников полиции, а также военнослужащих внутренних войск.

Для выполнения требований, закрепленных в приказе, в 2012 г. был создан отдел защиты законных интересов должностных лиц органов полиции и внутренних войск, решающий такие задачи, как:

- разработка и принятие правовых и организационных механизмов охраны основных прав, свобод должностных лиц внутренних войск и органов полиции;

- разработка предложений по совершенствованию механизма защиты законных интересов служащих внутренних войск и сотрудников полиции;

- разработка проектов нормативных актов, анализ и обработка предложений, связанных с устранением нарушений прав и законных интересов в служебной деятельности служащих внутренних войск и сотрудников полиции [15, с. 148-150].

Также государственная защита сотрудников полиции включает в себя социальное обеспечение. Меры социальной защиты персонала пенитенциарных учреждений Монголии, которые закреплены в Кодексе об исполнении судебных решений, таковы:

- в случае смерти (гибели) сотрудника исправительного учреждения при исполнении им служебных обязанностей его родным и близким производится единовременная выплата в размере должностного оклада за пять лет;

- персонал учреждений, выполняющий обязанности в круглосуточном режиме, обеспечивается за счет заведения бесплатным питанием; 
- дополнительные надбавки к окладу денежного содержания (за службу с заключенными, выслугу в государственной специальной службе, исключительные условия службы, специальное звание и т. д.).

Меры социальной поддержки в рамках пенсионного обеспечения сотрудников полиции Монголии, предусмотренные законом о пенсиях и пособиях, играют существенную роль в укреплении престижа государственной службы в полиции. К их числу относят:

- право на получение пенсии с трудовым стажем не менее 25 лет для мужчин и не менее 20 лет для женщин;

- размер пенсии определяется из расчета 80 \% от среднемесячного оклада денежного содержания;

- устанавливается надбавка к пенсии в размере 1,5 \% за каждый год службы сверх срока, дающего право на пенсию;

- при выходе на пенсию выплачивается единовременное пособие в размере 36 денежных окладов, половину из которого по желанию можно получить заранее - до освобождения от службы после возникновения права на пенсию [9, с. 50].

Таким образом, защитные меры в отношении сотрудников в Монголии практически затрагивают только социальную сферу, оставляя в тени обеспечение личной безопасности (кроме необходимой обороны). Это говорит о том, что в Монголии следует более тщательно урегулировать на законодательном уровне вопрос о защите сотрудников при угрозе их жизни и здоровью.

В Японии обеспечение государственной защиты судей, должностных лиц полиции, сотрудников исправительных учреждений регламентировано рядом правовых актов, в числе которых Основной закон государства, уголовный и процессуальный кодексы, законы о прокуратуре, полиции и др. Консолидированного нормативного акта, регулирующего отношения, возникающие по поводу обеспечения государственной защиты должностных лиц правоохранительных и контролирующих органов, нет. Соответствующая работа осуществляется в рамках повседневной правоохранительной деятельности национальной полиции.

Как утверждает М. Баттон, распространенной практикой в ряде зарубежных стран является обращение сотрудников правоохранительных органов для обеспечения личной безопасности в частные охранные структуры [20, с. 39-55]. При возникновении угроз в отношении сотрудников пенитенциарных учреждений на основании их письменного обращения полиция может применить усиленные защитные меры. Нормативно закрепленного перечня государственных служащих, подлежащих государственной защите, в Японии нет. Правом на повседневную защиту силами специального подразделения полиции (special police) обладают только действующий премьерминистр страны и император [6, с. 45].

Таким образом, правовая основа государственной защиты персонала пенитенциарных учреждений Монголии и Японии не приобрела унифицированной формы. Нормы, закрепляющие правовые и социальные гарантии сотрудников, содержатся в нескольких законах и конкретизирующих их подзаконных актах.

Исследовав опыт Монголии и Японии по исполнению защитных мер в отношении персонала исправительных учреждений, остановимся на рассмотрении практики представителей заключительной группы стран Западной Европы и Америки.

Прообраз российского института государственной защиты существует во многих развитых странах Европы и США.

Стоит рассмотреть опыт организации государственной защиты в Италии, где для этого сформировалась определенная система органов и сложился механизм включения в нее лиц, подлежащих государственной защите.

В Италии исполнением мер безопасности в отношении защищаемых лиц занимается Центральная служба защиты. Данное подразделение учреждено в составе Департамента общественной безопасности в 1991 г. В его состав входят дивизионы, осуществляющие специфические функции, такие как охрана осведомителей, охрана свидетелей, дивизион общих дел, управление и бухгалтерия. Дивизион общих дел занимается сопровождением деятельности всех остальных дивизионов, поддерживает взаимодействие с иностранными государствами, реализует юридическое, кадровое и документационное, медицинское обеспечение, а также осуществляет научно-исследовательскую работу.

Центральная служба защиты является непосредственным исполнителем конкретной меры (комплекса мер) безопасности в отношении защищаемого лица, а разраба- 
тывает программы по защите и принимает решение о применении меры безопасности (комплекса мер) комиссия - коллегиальный (совещательный) орган.

Руководство совещательным органом осуществляет должностное лицо МВД Италии в ранге заместителя министра, в его состав входят судьи, специалисты, обладающие необходимыми познаниями в области борьбы с мафией, а также прокурор, который предлагает кандидатуру лица, в отношении которого реализуются защитные меры.

Комплекс защитных мероприятий включает в себя меры безопасности и социальные гарантии, а именно:

1. Основной защитной мерой является сокрытие охраняемого лица в безопасном месте. С учетом открытости границ внутри Евросоюза с реализацией данной меры проблем нет.

2. В совокупности с помещением в безопасное место может осуществляться замена документов. Указанная мера предусматривает замену всех имеющихся у защищаемого лица документов, которые выдаются на новую фамилию. Новые данные выбираются в соответствии с разработанной легендой, которой должны строго придерживаться защищаемые лица и их близкие. Отступление от установленных правил является основанием для отмены мер безопасности.

3. Изменение личных данных в информационных базах.

4. Оказание материальной помощи (ежемесячное пособие и оплата жилья) и др. [3, c. 32].

Реализация программы не привязана к срокам ее осуществления, основанием для ее прекращения является только полное устранение угрозы. Решение о прекращении программы также принимает центральная комиссия.

Финансирование данной программы ограничений не имеет. Служба защиты ежегодно представляет финансовый отчет в центральную комиссию, при необходимости привлекаются средства федерального бюджета.

Материально-ресурсное обеспечение государственной защиты, в том числе реализации мер безопасности персонала учреждений и органов УИС, в России производится за счет средств федерального бюджета, выделяемых на содержание учреждений и органов УИС. Применение мер государ- ственной защиты в отношении персонала УИС на практике не носит повседневного характера, государственные органы функционируют в режиме бюджетной экономии, что свидетельствует о том, что финансирование рассматриваемой статьи расходов осуществляется по остаточному принципу. Институт государственной защиты судей, должностных лиц правоохранительных и контролирующих органов не имеет самостоятельной государственной программы финансирования, тогда как, к примеру, институт государственной защиты потерпевших, свидетелей и иных участников уголовного судопроизводства обладает таковой: государственная программа финансирования на период 2019-2023 гг., утвержденная постановлением Правительства Российской Федерации от 25.10.2018 № 1272, содержит конкретные финансовые показатели затрат на указанные цели и принципы распределения средств между органами, обеспечивающими безопасность.

47,8 \% респондентов из числа сотрудников УИС высказались за финансирование государственной защиты судей, должностных лиц правоохранительных и контролирующих органов, в том числе сотрудников УИС, в рамках самостоятельной федеральной программы.

Интересным представляется опыт обеспечения безопасности защищаемых лиц в Германии. По мнению Г. Межко, внимания здесь прежде всего заслуживает реализация защитной меры в виде сохранения в тайне персональных данных об охраняемом лице. При исполнении защитных мер компетентные органы часто сталкиваются с проблемой использования методов биометрической идентификации в различных коммерческих организациях [19, с. 189199]. Отпечатки пальцев рук, сканирование радужной оболочки глаз, система распознавания голоса, иные биометрические данные используются как идентификатор для пропуска на объекты либо в определенные помещения. Постоянный технологический рост в данной области негативно отражается на сохранении в тайне персональных данных легендированных персон, правоохранительным органам становится все сложнее обеспечить безопасность защищаемых [3, с. 32]. Государственные органы должны двигаться в ногу с развитием технологий и совершенствовать техническое обеспечение оперативно-служебной деятельности. 
В связи с указанными обстоятельствами российским органам, обеспечивающим безопасность защищаемых лиц, необходимо совершенствовать используемые механизмы с учетом развития сферы высоких технологий, при этом вопрос о государственном финансировании и его объемах приобретает первостепенное значение.

В Германии в ходе реализации программы защиты свидетелей специальными подразделениями, входящими в состав Федерального ведомства криминальной полиции, земельных ведомств криминальной полиции, были выявлены проблемы, связанные с применением такой меры безопасности, как обеспечение конфиденциальности и замена документов в отношении защищаемых лиц, а именно: когда защищаемое лицо меняло анкетные данные, соответственно и документы, при наличии обязательств у защищаемого лица перед третьими лицами (алименты, кредитные обязательства, налоги и т. д.) права последних не принимались во внимание, попросту нарушались. В связи с этим было введено положение о том, что защищаемое лицо обязано сообщать о наличии возможных правопритязаний третьих лиц, а в обязанность подразделений вменяется обеспечение контакта защищаемого лица с третьим лицом в условиях конфиденциальности с тем, чтобы урегулировать возникшие претензии [7, с. 53-54].

В Австрии, Голландии, Германии решение об осуществлении государственной защиты принимается в течение трех месяцев, в Российской Федерации - в течение трех дней. Продолжительный срок позволяет компетентным правоохранительным органам более тщательно проверять информацию о наличии угрозы и ее реальности и принимать более обоснованные решения. Обратная сторона такого подхода состоит в том, что преступникам для реализации своих угроз не требуется много времени.

Во многих странах мира деятельность по повышению уровня защищенности должностных лиц контролирующих и правоохранительных органов и лиц, оказывающих содействие правосудию, сконцентрирована в руках специально созданного органа, единого координационного центра. Так, в США это служба маршалов Министерства юстиции, в Италии и Германии - специальные подразделения уголовной полиции. Многоплановость проводимых мероприятий по обеспечению безопасности защища- емых лиц, осуществление согласованной аналитической и методической работы обусловливает необходимость сосредоточения единых организационных и правовых механизмов в одном месте [17, с. 64-65]. По мнению О. А. Зайцева, подобная структура в России может именоваться Управлением государственной защиты должностных лиц и некоторых категорий граждан.

С экономической точки зрения существование в России системы правоохранительных органов, осуществляющих государственную защиту, лишь на первый взгляд обеспечивает экономию средств. Как показывает практика, реализация государственной защиты является не свойственной указанным правоохранительным органам функцией, что значительно снижает продуктивность проводимых мероприятий, а также повышает расходы на обучение персонала, обеспечение материальными ресурсами [4, c. 53].

Создание отдельной структуры рационально и с точки зрения эффективности управленческой деятельности, так как раздробленная система правоохранительных органов в России не отвечает требованию единообразного подхода в правоприменительной практике.

Так, 43,2 \% респондентов из числа сотрудников УИС видят решение проблемы повышения эффективности государственной защиты в осуществлении указанной деятельности единым органом исполнительной власти, в частности МВД России (10,2 \% опрошенных) или ФСБ России (30,0 \% опрошенных). Одним из альтернативных решений может быть создание специальных подразделений по обеспечению государственной защиты защищаемых лиц на базе Федеральной службы войск национальной гвардии (далее - Росгвардия), поскольку некоторые специальные подразделения (ОМОН, СОБР и др.) переподчинены именно ей.

Вопрос о значении обучения персонала специфическим приемам и методам обеспечения государственной защиты в правоприменительной практике США и Канады был изучен Мелиссой Ковальски. Автор отметила, что на начальном этапе формирования подразделений государственной защиты США (маршальская служба) и Канады (Канадская королевская конная полиция) в рамках реализации программ защиты свидетелей столкнулись с такой проблемой, как 
отсутствие подготовленных кадров. В нескольких случаях это стало причиной провала защитных мер в отношении ключевых свидетелей: в результате посягательств представителей организованных преступных сообществ погибли защищаемые лица и сотрудники правоохранительных органов, обеспечивавшие их защиту. В связи с этим были образованы подразделения по подготовке и повышению квалификации для сотрудников отделов защиты участников уголовного судопроизводства [18, с. 98-125].

В процессе профессиональной подготовки должностных лиц правоохранительных органов многих иностранных государств, в том числе Америки, используются программы «Педагогика индивидуальной безопасности», «Воля к выживанию», «Выживание на улице» и др. Обучение по ним является обязательным для каждого сотрудника ФБР и других правоохранительных органов [2, c. 34]. Начинается оно с формирования установки на готовность к ситуации по принятию мер по обеспечению личной безопасности в профессиональном и психологическом плане [16, с. 7]. Иначе говоря, сотрудника мотивируют на принятие личных (индивидуальных) мер для обеспечения собственной безопасности.

Еще одним способом повышения эффективности и обоснованности реализации мер безопасности, по мнению И. С. Иванова, может стать установление обязательного судебного порядка вынесения решения о применении мер безопасности. В настоящее время в соответствии с ч. 1 ст. 14 Закона о государственной защите такое решение принимает должностное лицо органа, обеспечивающего безопасность [5, с. 38-42].

\section{Результаты}

Подводя итог, необходимо отметить, что правовые и организационные аспекты обеспечения государственной защиты персонала пенитенциарных учреждений некоторых зарубежных стран содержат как негативные, так и положительные моменты. На основании анализа иностранного опыта следует сделать вывод о том, что огромное внимание за границей уделяется институту государственной защиты лиц, содействующих правосудию. Отдельные черты организации защиты государственных служащих в таких странах, как США, Германия, Италия и др., могут получить распространение в Российской Федерации.

В целях эффективного управления и рационального расходования денежных средств, на наш взгляд, необходимо сосредоточить имеющийся потенциал института государственной защиты в рамках единого федерального органа, который может функционировать на базе Росгвардии.

Для повышения эффективности реализации положений Закона о государственной защите, должного финансового и материально-технического обеспечения выполнения мер государственной защиты предлагаем на правительственном уровне принять государственную программу финансирования мер безопасности в отношении судей, должностных лиц правоохранительных и контролирующих органов сроком на пять лет (2022-2027 гг.). В ней следует предусмотреть конкретные денежные ассигнования для осуществления всех запланированных мероприятий, распределение средств на реализацию конкретных мер безопасности.

На основании опыта коллег из Германии следует заключить, что интересы иных лиц, которые имеют имущественные и неимущественные претензии (налоги, алименты, кредиты и т. д.) к защищаемым, должны быть приняты во внимание и по возможности максимально разрешены. Для реализации данного положения на практике необходимо законодательно дополнить обязанности защищаемого лица положением об обязательном извещении о наличии к нему имущественных и неимущественных требований третьих лиц.

\section{СПИСОК ЛИТЕРАТУРЫ}

1. Батаев, М. Правовой статус сотрудника монгольской полиции: теоретико-правовой аспект : автореферат диссертации на соискание ученой степени кандидата юридических наук / Батаев Майдар. - Санкт-Петербург, 2005. 25 c.

2. Буданов, А. В. Обучение сотрудников правоохранительных органов тактике и методам обеспечения личной безопасности : учебно-практическое пособие / А. В. Буданов. - Москва : Методический центр при Главном управлении кадров МВД России, 1997. - 56 с.

3. Василевский, А. Опыт европейских государств по обеспечению безопасности лиц, подлежащих государственной защите (на примере Италии и Германии) / А. Василевский // Профессионал. - 2015. - № 3 (128). - С. $32-34$.

4. Зайцев, О. А. Теоретические и правовые основы государственной защиты участников уголовного судопроизводства : диссертация на соискание ученой степени доктора юридических наук / Зайцев Олег Александрович. - Москва, 1999. - 446 с. 
5. Иванов, И. С. Административно-правовое обеспечение безопасности участников уголовного судопроизводства в России / И. С. Иванов // Административное право и процесс. - 2011. - № 11. - С. 38-42.

6. Иванов, И. С. Переселение защищаемого лица на другое постоянное место жительства в отечественном и зарубежном праве / И. С. Иванов // Российский следователь. - 2013. - № 6. - С. 41-47.

7. Лукинский, А. В. Становление и развитие института государственной защиты (историко-правовое исследование) : диссертация на соискание ученой степени кандидата юридических наук / Лукинский Антон Владимирович. Москва, 2013. - 184 с.

8. Мельникова, Н. А. Зарубежный опыт стран СНГ в обеспечении государственной защиты персонала пенитенциарных учреждений / Н. А. Мельникова, О. В. Кириловский // Wschodnioeuropejskie Czasopismo Naukowe. - 2016. - Том 14, № 3. - C. 112-116. - URL: https://www.elibrary.ru/download/elibrary_28082708_91867043.pdf (дата обращения : 24.02.2021).

9. Наваан, Г. Особенности пенитенциарной системы Монголии: тенденции ее реформирования / Гантулга Наваан // Международный пенитенциарный журнал. - 2015. - № 1. - C. 49-51. - URL: https://www.elibrary.ru/download/ elibrary 24927411 77694680.pdf (дата обращения: 24.02.2021).

10. Основные показатели деятельности уголовно-исполнительной системы ФСИН России за 2016 год : информационно-аналитический сборник. - Тверь : ФКУ НИИИТ ФСИН России, 2017. - 385 с.

11. Основные показатели деятельности уголовно-исполнительной системы ФСИН России за 2017 г. : информационно-аналитический сборник. - Тверь : ФКУ нИИИТ ФСИН России, 2018. - 393 с.

12. Основные показатели деятельности уголовно-исполнительной системы ФСИН России за 2018 г. : информационно-аналитический сборник. - Тверь : ФКУ НИИИТ ФСИН России, 2019. - 328 с.

13. Основные показатели деятельности уголовно-исполнительной системы ФСИН России за 2019 г. : информационно-аналитический сборник. - Тверь : ФКУ НИИИТ ФСИН России, 2020. - 359 с.

14. Цэрэнбат, 3. Административно-правовая защита сотрудников полиции Монголии : диссертация на соискание ученой степени кандидата юридических наук / Цэрэнбат Зэвэгийл. - Москва, 2014. - 205 с.

15. Цэрэнбат, 3. Основы административно-правовой защиты сотрудников полиции Монголии / З. Цэрэнбат // Вестник Московского университета МВД России. - 2013. - № 12. - С. 148-150.

16. Чернов, А. И. Организация личной безопасности сотрудников органов внутренних дел : учебное пособие / А. И. Чернов. - Домодедово : ВИПК МВД России, 2001. - 76 с.

17. Ширитов, А. Б. Государственная защита участников уголовного судопроизводства: проблемы уголовно-процессуального регулирования : диссертация на соискание ученой степени кандидата юридических наук / Ширитов Арсен Барасбиевич. - Краснодар, 2011. - 215 с.

18. Kowalski, M. Hiring and Training Requirements for Correctional Officers: A Statutory Analysis / Melissa A. Kowalski // The prison journal. - 2020. - Volume 100, no 1. - Pp. 98-125. - DOI 10.1177/0032885519882342. - URL: https://journals. sagepub.com/doi/full/10.1177/0032885519882342 (дата обращения: 20.02.2021).

19. Me ko, G. On some aspects of cybercrime and cybervictimization / Gorazd Me ko // European journal of crime, criminal law and criminal justice. 2018. - Volume 26, no. 3. - Pp. 189-199. - DOI 10.1163/15718174-02603006. - URL: https:// www.deepdyve.com/lp/brill/on-some-aspects-of-cybercrime-and-cybervictimization-QzXh8LLMr0?key=brill (дата обращения: 24.02.2021).

20. Button, $\mathrm{M}$. The «New» private security industry, the private policing of cyberspace and the regulatory questions / Mark Button // Journal of contemporary criminal justice. - 2020. - Volume 36, no. 1. - Pp. 39-55. DOI 10.1177/1043986219890194. - URL: https://journals.sagepub.com/doi/10.1177/1043986219890194\#articleShare Container (дата обращения: 24.02.2021).

\section{REFERENCES}

1. Bataev M. Pravovoi status sotrudnika mongol'skoi politsii: teoretiko-pravovoiaspekt: avtoreferat dissertatsii na soiskanie uchenoi stepeni kandidata yuridicheskikh nauk [Legal status of an employee of the Mongolian police: theoretical and legal aspect: Candidate of Sciences (Law) dissertation abstract]. Saint Petersburg, 2005.25 p.

2. Budanov A.V. Obuchenie sotrudnikov pravookhranitel'nykh organov taktike i metodam obespecheniya lichnoi bezopasnosti: uchebno-prakticheskoe posobie [Training of law enforcement officers in tactics and methods of ensuring personal security]. Moscow: Metodicheskii tsentr pri Glavnom upravlenii kadrov MVD Rossii, 1997. 56 p.

3. Vasilevskii A. The experience of European states in ensuring the security of persons subject to state protection (on the example of Italy and Germany). Professional, 2015,no. 3 (128), pp. 32-34.(In Russ.).

4. Zaitsev O.A. Teoreticheskie i pravovye osnovy gosudarstvennoi zashchity uchastnikov ugolovnogo sudoproizvodstva: dissertatsiya na soiskanie uchenoi stepeni doktora yuridicheskikh nauk [Theoretical and legal foundations of state protection of participants in criminal proceedings: Doctor of Sciences (Law) dissertation]. Moscow, 1999.446 p.

5. Ivanov I.S. Administrative and legal support for the security of participants in criminal proceedings in Russia Administrativnoe pravo i protsess=Administrative Law and Process, 2011, no. 11, pp. 38-42. (In Russ.).

6. Ivanov I.S. Relocation of the protected person to another permanent place of residence in domestic and foreign law. Rossiiskii sledovatel'=Russian Investigator, 2013, no. 6, pp. 41-47. (In Russ.).

7. Lukinskii A.V. Stanovlenie i razvitie instituta gosudarstvennoi zashchity (istoriko-pravovoe issledovanie): dissertatsiya na soiskanie uchenoi stepeni kandidata yuridicheskikh nauk [Formation and development of the institution of state protection (historical and legal research): Candidate of Sciences (Law) dissertation]. Moscow, 2013. 184 p.

8. Mel'nikova N.A., Kirilovskii O.V. Foreign experience of the CIS countries in providing state protection of personnel of penitentiary institutions. Wschodnioeuropejskie Czasopismo Naukowe, 2016, vol. 14, no. 3, pp. 112-116. Available at: https://www.elibrary.ru/download/elibrary_28082708_91867043.pdf (accessed February 24, 2021).

9. Navaan G. Features of the penitentiary system of Mongolia: tendencies of its reform. Mezhdunarodnyi penitentsiarnyi zhurnal=International Penitentiary Journal, 2015, no. 1, pp. 49-51. Available at: https://www.elibrary.ru/download/ elibrary_24927411_77694680.pdf (accessed February 24, 2021).(In Russ.).

10. Osnovnye pokazateli deyatel'nostiugolovno-ispolnitel'noi sistemy FSIN Rossii za 2016 god: informatsionnoanaliticheskii sbornik [Key performance indicators of the penitentiary system of the Federal Penitentiary Service of Russia for 2016: information and analytical collection]. Tver: FKU NIIIT FSIN Rossii, 2017. P. 33. 
11. Osnovnye pokazateli deyatel'nosti ugolovno-ispolnitel'noisistemy FSIN Rossii za 2017 g.: informatsionno-analiticheskii sbornik [Key performance indicators of the penitentiary system of the Federal Penitentiary Service of Russia for 2017: information and analytical collection]. Tver: FKU NIIIT FSIN Rossii, 2018. P. 39.

12. Osnovnye pokazateli deyatel'nosti ugolovno-ispolnitel'noi sistemy FSIN Rossiiza 2018 g.: informatsionno-analiticheskii sbornik [Key performance indicators of the penitentiary system of the Federal Penitentiary Service of Russia for 2018 : information and analytical collection]. Tver: FKU NIIIT FSIN Rossii, 2019. P. 38.

13. Osnovnye pokazateli deyatel'nosti ugolovno-ispolnitel'noi sistemy FSIN Rossii za 2019 g.: informatsionno-analiticheskii sbornik [Key performance indicators of the penitentiary system of the Federal Penitentiary Service of Russia for 2019: information and analytical collection]. Tver: FKU NIIIT FSIN Rossii, 2020. Pp. 19-34.

14. Tserenbat Z. Administrativno-pravovaya zashchita sotrudnikov politsii Mongolii: dissertatsiyanasoiskanieuchenoistep enikandidatayuridicheskikhnauk [Administrative and legal protection of police officers in Mongolia: Candidate of Sciences (Law) dissertation]. Moscow, 2014.205 p.

15. Tserenbat Z. Fundamentals of administrative and legal protection of police officers in Mongolia. Vestnik Moskovskogo universiteta MVD Rossii=Bulletin of the Moscow University of the Ministry of Internal Affairs of Russia, 2013, no. 12, pp. 148-150. (In Russ.).

16. Chernov A.I. Organizatsiya lichnoi bezopasnosti sotrudnikov organov vnutrennikh del: uchebnoeposobie [Organization of personal security of employees of internal affairs bodies: a textbook]. Domodedovo: VIPK MVD Rossii, 2001. 76 p.

17. Shiritov A.B. Gosudarstvennaya zashchita uchastnikov ugolovnogo sudoproizvodstva: problem ugolovnoprotsessual'nogo regulirovaniya: dissertatsiya na soiskanie uchenoi stepeni kandidata yuridicheskikh nauk [State protection of participants in criminal proceedings: problems of criminal procedure regulation: Candidate of Sciences (Law) dissertation]. Krasnodar, 2011.215 p.

18. Kowalski M.A. Hiring and training requirements for correctional officers: a statutory analysis. The Prison Journal, January 2020, vol. 100, no 1, pp. 98-125. DOI:10.1177/0032885519882342. Available at: https://journals.sagepub.com/ doi/full/10.1177/0032885519882342 (accessed February 20, 2021).

19. Mesko G. On some aspects of cybercrime and cybervictimization. European Journal of Crime, Criminal Law and Criminal Justice, 2018, vol. 26, no. 3, pp. 189-199. DOI: 10.1163/15718174-02603006. Available at: https://www.deepdyve.com/ Ip/brill/on-some-aspects-of-cybercrime-and-cybervictimization-QzXh8LLMr0?key=brill (accessed February 24, 2021). 20. Button M. The "New" private security industry, the private policing of cyberspace and the regulatory questions. Journal of Contemporary Criminal Justice, 2020, vol. 36, no. 1, pp. 39-55. DOI: 10.1177/1043986219890194. Available at: https:// journals.sagepub.com/doi/10.1177/1043986219890194\#articleShareContainer (accessed February 24, 2021).

\section{CВЕДЕНИЯ ОБ АВТOPE / INFORMATION ABOUT THE AUTHOR}

ОЛЕГ ВАЛЕРЬЕВИЧ КИРИЛОВСКИЙ - СТарШИЙ Преподаватель кафедры административно-правовых дисциплин юридического факультета ВИПЭ ФСИН России, г. Вологда, Российская Федерация. ORCID: https://orcid. org/: 0000-0001-8718-396X, e-mail: kirilovskiy77@mail.ru
OLEG V. KIRILOVSKII - Senior Lecturer at the Department of Administrative and Legal Disciplines, Faculty of Law, Vologda Institute of Law and Economics of FSIN Russia, Vologda, Russian Federation. ORCID: https://orcid. org/0000-0001-8718-396X, e-mail: kirilovskiy77@mail.ru 